\title{
Protein Characterization of Extracted Water from Three Kinds of Edible Bird Nest Using SDS-PAGE CBB Staining and SDS- PAGE Glycoprotein Staining and LC-MS/MS Analyses
}

\author{
Budi Utomo ${ }^{1)}$, D Rosyidi ${ }^{2)}$, LE Radiati ${ }^{2}$,NNT Puspaningsih ${ }^{3)}$, WD Proborini ${ }^{4)}$ \\ ${ }^{I}$ Postgraduate Program, Faculty of Animal Husbandry, University of Brawijaya. Malang-Indonesia \\ ${ }^{2}$ Faculty of Animal Husbandry, University of Brawijaya. Jl. Veteran, Malang-Indonesia \\ ${ }^{3}$ Faculty of Science and Technology, Airlangga University Jl. Airlangga, Surabaya-Indonesia \\ ${ }^{4}$ University of Tribuana Tungga Dewi, Malang-Indonesia
}

\begin{abstract}
The objective of this research is to see the comparison of protein characterization from three kinds of Indonesia edible bird nest as they have not been researched before. This research would give us overall picture on protein characteristics of the three Indonesian edible bird's nests, so it could show their activeness compared to the white edible bird nest. This research was a laboratory research with three treatments and five parameters. Treatments in this research was conducted on three kinds of edible bird nest, the white edible bird nest (Collocaliafuciphaga), the black edible bird nest (Collocalia maxima) and the swallow edible bird nest (Collocalialinchi). Parameters measured in this research were protein content, glycoprotein content, SDSPAGE (Sodium Dodecyl Sulfate Polyacrylamide Gel) CBB (Coomassie brilliant blue) staining, SDS-PAGE (Sodium Dodecyl Sulfate Polyacrylamide Gel) glycoprotein staining and LC-MS/MS(Liquid Chromatographymass Spectroscopy/mass spectroscopy) analysis. It was an explorative research. The method used was trial method with randomized complete design (protein and glycoprotein content) and descriptive method. The analyses results on protein and glycoprotein content from the three Indonesian edible bird nests were different and presumably due to their different kinds of feed. Protein characterization using SDS-PAGE CBB staining showed protein band high intensity on various molecular weights. They are 140.8; $64.8 ; 21.2 \mathrm{kDa}$ for the white edible bird nest, 27.1; 21.2; $15.2 \mathrm{kDa}$ for the black edible bird nest, and 140.8; 116; $36.2 \mathrm{kDa}$ for the swallow edible bird nest. Glycoprotein characterization using SDS-PAGE glycoprotein staining showed different results; 140.8 and $64.8 \mathrm{kDa}$ for the white edible bird nest; 140.8 and $116.0 \mathrm{kDa}$ for the swallow edible bird nest; 28.4 and $105.3 \mathrm{kDa}$ for the black edible bird nest. Analysis results using LC-MS/MS showed the presence of glycoprotein in the white edible bird nest but none was found in the black and the swallow edible bird nest.
\end{abstract}

Key Words:edible bird nest, characterization protein, protein bird nest

\section{Introduction}

Edible bird nest was healthy food of Chinese kings. The Chinese believes that edible bird nest was antiaging supplement. Researches have been conducted to prove its benefits for health. A lot of those researches showed the benefits of edible bird nest for people's health. According to Guo, Takahashi, Bukawa, Takahashi, Yagi, Kato, Hidari, Miyamoto, Suzuki and Suzuki (2006), edible bird nest extract was able to impede the infection of influenza virus. A research conducted by Roh, Lee, Kim, Park, Kim, Lee, Park (2012) showed that the Chinese belief on edible bird nest as an anti-aging supplement was right. Edible bird nest extract was able to improve stem cells' growth in the body. Ma and Liu (2012) concluded in their review that the extract benefit for health was due to its major bioactive compound that is its protein. The active protein is glycoprotein and so it is an important content of edible bird nest other than previous qualities explained above.

Researches on the edible bird nests' benefits for health which were commonly conducted used bird's nest of Collocaliafuciphaga bird. This bird's nest is commonly called the white edible bird nest in Indonesia. It is one from three kinds of edible bird nest commonly harvested in Indonesia. Indonesia has three kinds of edible bird nest commonly harvested. The first is white edible bird nest produced by Collocaliafuciphaga, the second is black edible bird nest produced by Collocalia maxima, and the third is swallow edible bird nest produced by Collocalialinchi (Mardiastuti, 1997).

The black and the swallow edible bird's nests have not been researched yet in terms of their benefits for health. The research for those two edible bird nests' benefits for health can be started on their protein characteristic compared to the white edible bird nest (Liu et al, 2012). The research conducted by Liu et al (2012) focused on the white edible bird nest protein profile from a few countries such as Indonesia, Malaysia, Thailand and Vietnam and found that there were three types which showed dissimilarity on SDS-PAGE analysis especially on the molecular weight between taxa A and taxa D bird's nests about $50 \mathrm{KDa}$ and 66KDa. This protein difference causes different impact of benefits on health. 
The objective of this research is to see the comparison of protein characterization from three kinds of Indonesia edible bird nest as they have not been researched before. This research would give us overall picture on protein characteristics of the three Indonesian edible bird's nests, so it could show their activeness compared to the white edible bird nest.

\subsection{Material}

\section{Material And Method}

Three kinds of edible bird nest used were acquired in Indonesia. The white and the swallow edible bird nests were from edible bird nest farm in the town of Banyuwangi. The black edible bird nest was acquired from a cave in Aceh.

\subsection{MaterialPreparation}

Acquired edible bird nest was washed using enzymatic method (Utomo, 2010). The edible bird nest protein extract was acquired by soaking the nest in distilled water and kept in $5^{\circ} \mathrm{C}$ temperature for 16 hours and then it was heated in $100^{\circ} \mathrm{C}$ temperature for 30 minutes. After that, it was filtered and the water was extracted. The water from the soaking was precipitated with cold absolute acetone for 2 hours, 1:2 of deposits was separated using $6000 \mathrm{~g}$ cold centrifuge for 30 minutes. Separated deposit then was dried and solved in distilled water as the solvent for the next analyses (Guoet al, 2006 danHidayat 2001).

\subsection{Analyses}

Glycoprotein content analysis used Glycoprotein Carbohydrate Estimation (Gates, 2004). Protein content test used Proximate analysis (Marcone, 2005), and glycoprotein identification used SDS-PAGE glycoprotein staining with GelCode Glycoprotein Staning Kit method (Gates, 2004), LC-MS/MS (Andersen dan Packer, 2014).

\subsection{Data analyses}

This research was a laboratory research with three treatments and five parameters. Treatments in this research was conducted on three kinds of edible bird nest, the white edible bird nest (Collocaliafuciphaga), the black edible bird nest (Collocalia maxima) and the swallow edible bird nest (Collocalialinchi). Parameters measured in this research were protein content, glycoprotein content, amino acid profile, SDS-PAGE CBB (Coomassie brilliant blue) staining, SDS-PAGE glycoprotein staining and glycoprotein identification analysis with LC-MS/MS (Andersen dan Packer, 2014) which was modified and confirmed with standard glycoprotein (Sigma-aldrich catalogue10408). This research was an explorative research. The data analyses were conducted descriptively.

\section{Discussion \\ 3.1 Protein and Glycoprotein Content Analysis from Three Kinds of Edible Bird Nest}

Table I. Protein and Glycoprotein Content from Three Kinds of Indonesian Edible Bird Nest

\begin{tabular}{lll}
\hline Edible bird nest kind & Protein Content (\%) & Glycoprotein levels (\%) \\
\hline The white edible bird nest & $60.03 \pm 0.74$ & $19.7 \pm 2.9 \mathrm{a}$ \\
The black edible bird nest & $54.86 \pm 0.72$ & $7 \pm 1 \mathrm{~b}$ \\
The swallow edible bird nest & $57.49 \pm 0.36$ & $15 \pm 0 \mathrm{c}$ \\
\hline
\end{tabular}

The protein and glycoprotein content analyses from the three kinds of edible bird nest can be seen in Table I. Protein content is one of many important contents in edible bird nest. Glycoprotein is one of some proteins which become major bioactive content in edible bird nest, the more protein and glycoprotein found in it the more benefits acquired from the edible bird nest for human's (Ma dan Liu, 2012). The highestprotein content from the three kinds of edible bird nest was acquired from the white edible bird nest and the lowest was from the black edible bird nest. Protein content of the swallow edible bird nest was between the white and the black one. Protein content of the white edible bird nestagreed with what Hamzah and Ibrahim (2013) reported that is about $60 \%$. Mahardika and Dadit (2011) reported that protein content in the swallow edible bird nest was about 55\%. Protein content of the black edible bird nest according to Saepudin (2007) was $37.65 \%$. Hamzah and Ibrahim (2013) reported the food type and its availability affected the protein content from a kind of edible bird nest in different places. The black edible bird nest from Saepudin research (2007) used edible bird nest from Bengkulu, while this research used edible bird nest from Aceh. Protein and glycoprotein content dissimilarity found in these three kinds edible bird nest was presumed due to the different feed type and metabolism which then affecting protein and glycoprotein content (Hamzah and Ibrahim, 2013). 


\section{SDS-PAGE CBB Staining on Water Extract Protein from Indonesian Three Kinds of Edible Bird Nest}

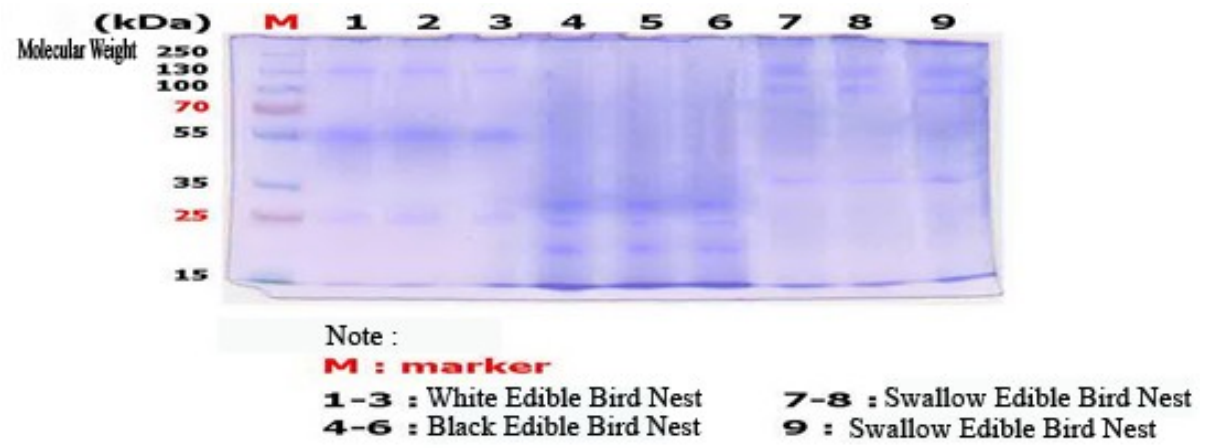

Figure 1. Protein SDS-PAGE from three kinds of Indonesian edible bird nest

Protein characterization on the bird nests was conducted with SDS-PAGE technique using 10\% separating gel. Protein staining was done with coomassie brilliant blue (CBB) method and glycoprotein staining. Molecular weight from the edible bird nest protein was measured using linear regression standard curve. The standard curve was acquired from plotting Rf value and molecular weight logarithmic value and from the linear regression we got this following equation:

$Y=-1,3484 x+2,3383$

Protein band acquired from the electrophoresis separation was substituted to linear regression equation (standard curve), so Y value was discovered. Y value showed the protein molecular weight.

Electrophoresis with $\mathrm{CBB}$ staining resulted different band for each edible bird nest sample. These bands difference showed the different protein molecular weight for each kind of edible bird nest. The white edible bird nest was formed thicker on molecular weight of 140.8; 64.8; 21.2 KDa, protein band high intensity also presented in the black edible bird nest on molecular weight of 27.1;21.2; 15.2 KDa. Protein band high intensity of the swallow edible bird nest was on molecular weight of 140.8; 116 dan $36.2 \mathrm{KDa}$.

According to Pasila (2008) protein band high intensity directly proportional to the protein abundance, while according to Tung et al (1995) in Mahasri (2010), protein band high intensity was influenced by genetically difference in each protein. Food and metabolism differences also affected the protein characteristic difference from these three kinds of Indonesian edible bird nest (Hamzahdan Ibrahim 2013). Protein presence in those three kinds of edible bird nest was shown by the band profile on SDS-PAGE with CBB staining method. The protein analysis result of SDS-PAGE from three kinds of Indonesian edible bird nest can be seen in Figure 1. CBB compound possessed molecular species color and a form differently depends on the acidity.

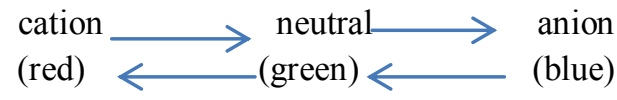

CBB formed non-covalent complex with protein through Van der Waals and electrostatic interaction where the complex would stabilize negatively charged CBB compound anionic form so it produced blue color. The number of complex compound formed was directly proportional to the number of protein per band.

SDS-PAGE Glycoprotein Staining on Water Extract Protein from Indonesian Three Kinds of Edible Bird Nest

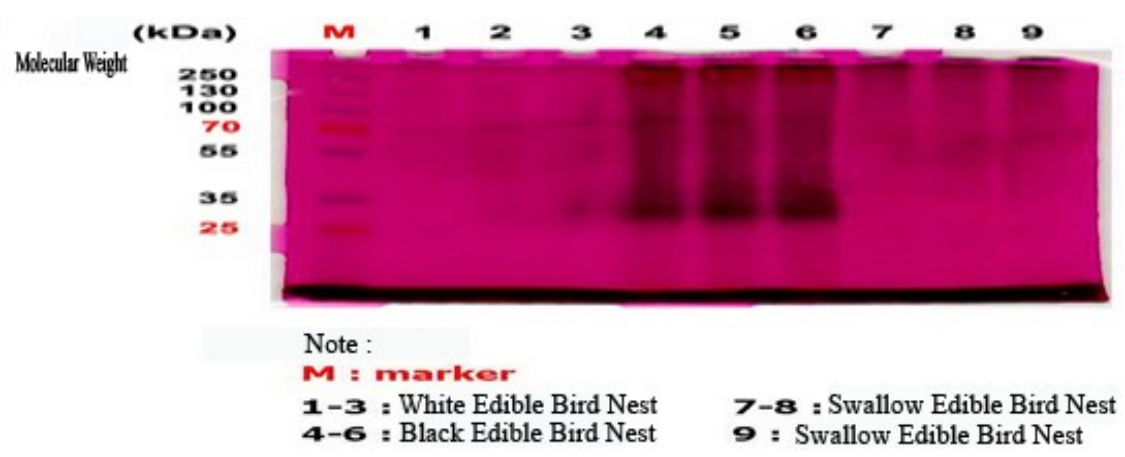

Figure 2. SDS-PAGE Glycoprotein Staining from three kinds of Indonesian edible bird nest

Glycoprotein molecular structure consists of covalently bonded polypeptides to carbohydrate moieties. This carbohydrate moieties ranged from $1 \%$ to more than $80 \%$ of total protein mass (McMurry, 2008). 
Glycoprotein staining was able to detect sugar (carbohydrate) moiety which was bonded (sugar linked molecules) to polyacrylamide gel and nitrocellulose membrane. Oxidating agent used in glycoprotein staining would oxidateglycan's in the glycoprotein into aldehyde and then staining was done to produce magenta colored band.

Glycoprotein staining results on the whiteedible bird nest, the black edible bird nest and the swallow edible bird nest showed sugar moieties which were bonded to the protein, in which there was magenta band with higher intensity in the black edible bird nest than the white or the swallow bird nests. The band intensity was equal to the number of bonded suger moieties.

High intensity band in the white edible bird nest presented on $95.5 \mathrm{kDa}$, and the swallow edible bird nest was on $78.7 \mathrm{kDa}$. This condition substantiated the notion on the presence of glycoprotein as also shown with Coomassie Blue staining where the while edible bird nestindicated the presence of glycoprotein on 140.8 $\mathrm{kDa}$ and $64.8 \mathrm{kDa}$. Similar indication was found with the swallow edible bird neston $140.8 \mathrm{kDa}$ and $116.0 \mathrm{kDa}$ but the black edible bird nestdid not show its band high intensity on glycoprotein range. Based on Glycoprotein Staining results, the black edible bird nest showed high intensity on $28.4 \mathrm{kDa}$ and $105.3 \mathrm{kDa}$ and this data did not show the presence of sugar moieties bonded to certain protein as there was no indication of glycoprotein on Coomassie Blue Staining results. This can be seen from the high intensity band which appeared only on 27.1 $\mathrm{kDa}, 21.2 \mathrm{kDa}$ and $15.2 \mathrm{kDa}$. The presence of high intensity band in Glycoprotein staining of the black edible bird nest was caused by unbounded carbohydrate (sugar) compound which solved in the water extract along with protein. Carbohydrate and protein are bio-macromolecule compounds and all of them have polarity properties which are almost similar as they have polar hydrophilic head and non-polar hydrophobic tail.

LC-MSMS analysis results were used to confirm the presence of glycoprotein in the three kinds of Indonesian edible bird nest. LC-MSMS was analyzed based on glycoprotein standard acquired from the sigma. The results showed that glycoprotein was only found in the white edible bird nestbut not found in the black and the swallow edible bird nests. Figure 3 showed glycoprotein reading in the three kinds of edible bird nest compared to the standard glycoprotein using LC-MSMS.

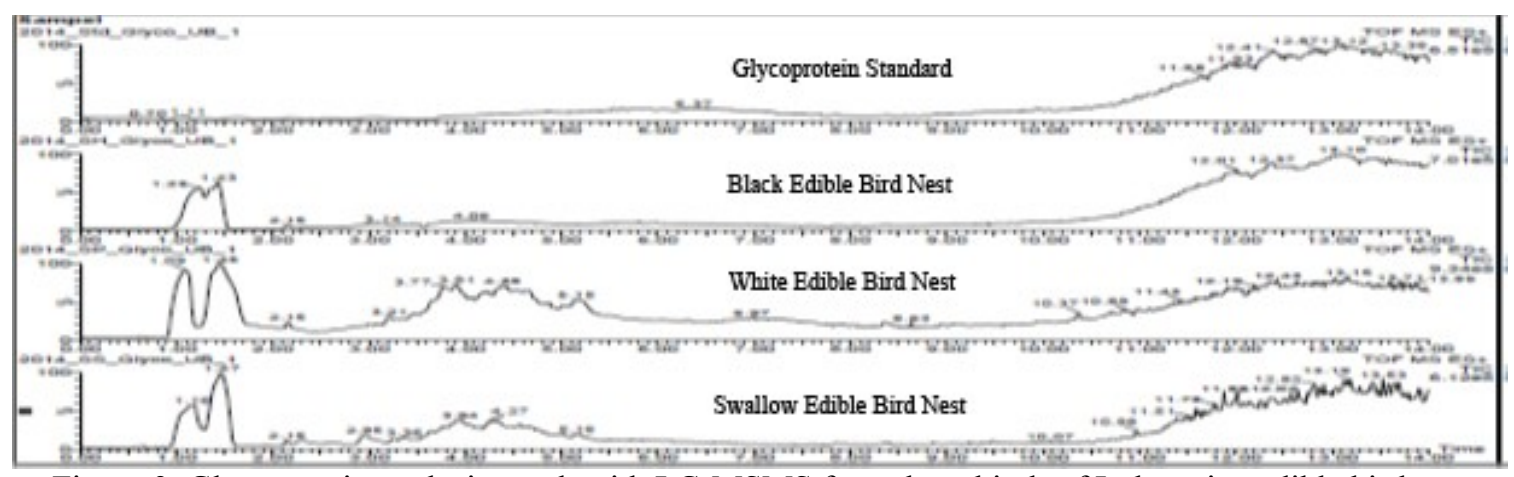

Figure 3. Glycoprotein analysis result with LC-MSMS from three kinds of Indonesian edible bird nest confirmed standardly

Analysis result on glycoprotein standard showed the presence of glycan moiety at $0.70-1.11$ retention time and protein moiety at 6.37 retention time. The result of standard glycoprotein analysis was similar to glycoprotein analysis on the white edible bird nest which showed sugar moiety at 1.09-1.45 retention time and protein moiety at 6.97 . The result of glycoprotein analysis on the black edible bird nest only showed peak on glycan moiety at 1.25-1.43 retention time and so was the result of glycoprotein analysis on the swallow edible bird nest, only showed peak on the glycan moiety at 1.19-1.47 retention time. These results were supported by SDS-PAGE analysis on standard glycoprotein.

The result of standard glycoprotein SDS-PAGE analysis showed protein band high intensity on molecular weight $60 \mathrm{kDa}$ on line 2. This result was similar to SDS-PAGE analysis on the white edible bird nest with protein band high intensity on molecular weight $64 \mathrm{kDa}$. The results of SDS-PAGE on the black and the swallow edible bird nests showed protein band high intensity below and above standard glycoprotein molecular weight. The molecular weight comparison of SDS-PAGE CBB staining between standard glycoprotein and protein in the white edible bird nest can be seen in Figure 4. 

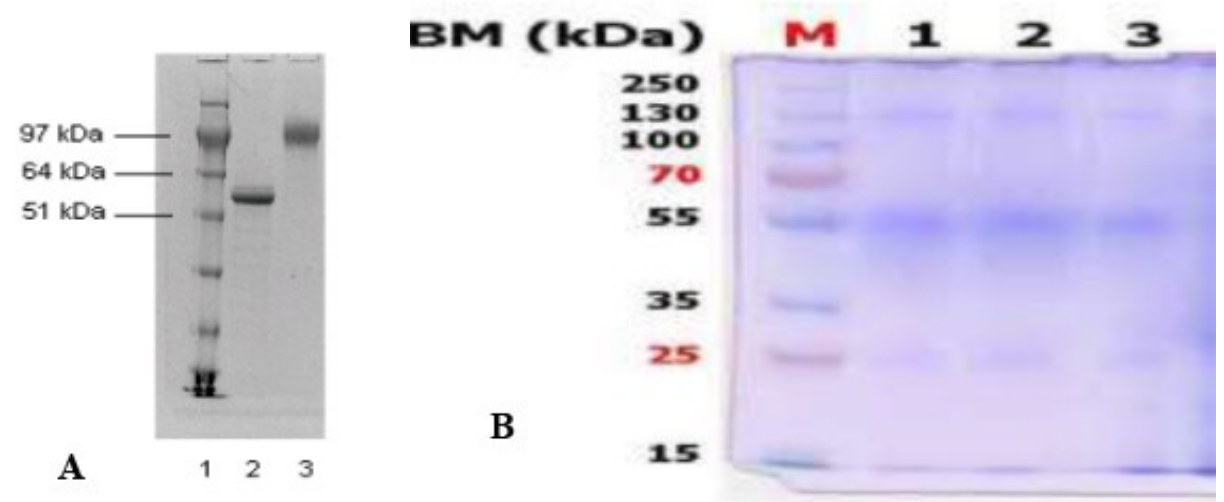

Figure 4.SDS-PAGE CBB staining (A line 2) on standard glycoprotein and SDS-PAGE CBB staining on the white edible bird nest (B line 123).

The result of SDS-PAGE CBB above showed that protein in the extracted water from the white edible bird nest was presumed to have glycoprotein content in the protein with molecular weight $64 \mathrm{kDa}$ based on SDSPAGE CBB staining and SDS-PAGE glikoprotein staining and confirmed by SDS-PAGE CBB staining on standard glycoprotein and also LC-MSMS. But the glycoprotein was not found in the protein of extracted water from the black edible bird nest based on SDS-PAGE CBB staining and SDS-PAGE glycoprotein staining and confirmed by SDS-PAGE CBB staining on standard glycoprotein and also LC-MSMS. Glycoprotein was not found in the protein of extracted water from the swallow edible bird nest based on SDS-PAGE CBB staining and confirmed by SDS-PAGE CBB staining on standard glycoprotein and also LC-MSMS but the presence is still probable. The result of glycoprotein analysis on the swallow edible bird nest using LC-MSMS showed the absence of glycoprotein. It was presumed due to the glycoprotein standard used was only one molecular weight and did not have the glycoprotein standard on bigger molecular weight.

\section{Conclusion}

Protein and glycoprotein content in the white edible bird nest, the black edible bird nest, and the swallow edible bird nest were different. The different content of protein and glycoprotein was presumed due to the different kinds of food and metabolism from the three kinds of edible bird nest. Protein characterization of water extracted from the swallow and the black edible bird nests were different from the protein characterization of water extracted from the white edible bird nest. This difference was presumed due to protein genetical differences from the three kinds of edible bird nest. Glycoprotein was only found in the protein of water extracted from the white edible bird nest but none had been found in the protein of water extracted from the swallow and the black edible bird nests.

\section{References}

[1] Andersen, M. T., and Nicolle H. Packer. 2014. Advances in LC-MS/MS-based glycoproteomics: Getting closer to system-wide site-specific mapping of the N- and O-glycoproteome. BiochimicaetBiophysicaActa 1844 (2014) 1437-1452.

[2] Gates, R., Rathbone, E., Materson, L., Wright, I. and Electricwala, A. 2004.Glycoprotein Analysis Manual.1 st Edition.Sigma.Poole. England.

[3] Guo, C., T. Takahashi,. W. Bukawa., N. Takahashi., H. Yagi., K. Kato., K. I.-P. JwaHidari., D. Miyamoto., T. Suzuki., and Y. Suzuki. 2006. Edible bird's nest extract inhibits influenza virus infection. Antiviral Research 70 (2006) 140-146.

[4] Hamzah, Z., N. Hulwani Ibrahim., S. J.,K. Hussin., O. Hashim., and B. Lee. 2013. Nutritional Properties Of Edible Bird Nest. Journal of Asian Scientific Research, 2013, 3(6):600-607.

[5] Hidayat, R. 2001. Glycoprotein Characteristic of Extracted Water from GanodermaLucidium. Thesis. Bogor Agricultural University. Bogor.

[6] Jong,C. H., K. MengTay., and C. Peng Lim. 2013. Application of the fuzzy Failure Mode and Effect Analysis methodology to edible bird nest processing. Computers and Electronics in Agriculture 96 (2013) 90-108.

[7] Liu, X., X. Lai., S. Zhang,. X. Huang., Q. Lan., Y. Li., B. Li., W. Chen., Q. Zhang., D. Hong., and G. Yang. 2012. Proteomic Profile of Edible Bird's Nest Proteins. Journal of Agricultural and. Food Chemistry. 2012, 60, 12477-12481.

[8] Ma, F., and D. Liu. 2012. Sketch of the edible bird's nest and its important bioactivities. Food Research International 48 (2012) $559-567$.

[9] Mahasri, G. Fajriah, U. Subekti, S. 2010. Protein Characterization of Lernaeacyprinacea using SDS-PAGE Electrophoresis Method. Fisheries and Marine Scientific Journal., Vol 2. No 1.p. 61-66.

[10] Marcone, M. F. 2005. Characterization of Edible Bird Nest the "Caviar of the East. Food Research International, 38 : $1125-1134$.

[11] Marsiastuti, A. 1997. Utilization of Edible Bird Nest Conservely. A Paper in Birds Potential Efficiency for Supporting National Development Seminar. Taman Mini Indonesia Indah Bird Aviary. Jakarta.

[12] McMurry, J. 2008. Organic Chemistry. $7^{\text {th }}$ edition.CornellUniversity.Thompson - Brooks/Cole. United States of America.

[13] Oda, M., Ohta, S., Suga, T. and Aoki, T. 1998. Study on Food Components: The Structure of N-Linked Asialo Carbohydrate from the Edible Bird's Nest Built by Collocaliafuciphaga. J. Agric. Chem., 46 :3047-3053.

[14] Pasila, A.R. 2008. Identification of Excretion-Secretion Protein Profile of The Adult HaemonchuscontortusWith SDS PAGE. Faculty of Veterinary Medicine. UniversitasAirlangga 
[15] Roh, Lee, Kim and Park. 2012. Mechanism od Edible Bird's Nest Extract Induced Stem Cells. Evidance Basic Complementary.AlternativeMedicine.Vol 2012.Article 10797520.

[16] Saepudin, R. 2007. The effect of Hydrogen Peroxide Consentration (H2O2) on the Brightness and Nutrient values of the Collocal ia maxima Edible Bird Nest. Indonesian Animal Agricultural Science Journal Volume 2, Number 1, Januari - Juni 2007.

[17] Suresh, B. S. V, Shareef, M. M., A. Shetty, A. P. K., and Shetty, K. T. 2002.HPLC Method for Amino Acids Profile in Biological Fluids and Inborn Metabolic Disorders of Aminoacidpathies.IndianJ.OfCliniacal Biochem.17 : 7-26

[18] Utomo, B. 2010. Keratinase Enzyme Utilization for the Washing of Edible Bird Nests.Thesis. University of Brawijaya. Malang. 